\title{
IMPLEMENTASI KEBIJAKAN PENCEGAHAN DAN \\ PENANGGULANGAN HUMAN IMMUNODEFICIENCY/AQUIRED \\ IMMUNE DEFICIENCY SYNDROME (HIV/AIDS) \\ DI KOTA SURAKARTA
}

\author{
Siti Wahyuningsih \\ e-mail: drsitiwahyuningsih@yahoo.co.id \\ Pegawai Dinas Kesehatan Kotamadya Surakarta \\ Widodo Tresno Novianto \\ email: novianto@consultant.com \\ Hari Purwadi \\ email : h_purwadie@yahoo.com \\ Dosen Fakultas Hukum Universitas Sebelas Maret
}

\begin{abstract}
This Articel to analyze the implementation of policy on the prevention and combat of Human Immunodefisiency Virus and Aquired Immune Deficiency Syndrome (HIVIAIDS) in Surakarta City. This type of research in writing this is a non-doctrinal/empirical, with basing on the concept of the law of the 5th. The form used is the research diagnostic analysis. The data type of the data source, and the primair include primary and secondary legal materials. Data analysis using qualitative analysis. Based on the results of research and discussion with respect to issues that are examined, it can be summed up as follows: (1) Factors that become the cause of inadequate response to the HIV and AIDS amongst others caused the problem of HIV and AIDS has not been considered a priority issue by the health sector as well as the development of related sectors; (2) the political support that has not been adequately against the program; (3) yet uncoordinated Commission Response AIDS (KPA) and the SKPD of Surakarta City either the direction of development, planning and implementation of policies and programs regarding the Decree despite various efforts for tackling even the financing has been issued; and (4) the still inadequate dissemination of information and access to health services and the availability of VCT services, ARV existence for sufferers and those at high risk with HIVIAIDS. The steps that must be performed in order to cope with HIVIAIDS in Surakarta, among others : (1) Aspects of the substance of the law with further strengthen runway operations mainly technical instructions and guidelines that govern the start of planning, implementation, evaluation, monitoring, sanctions; (2) Aspects of structure/ function and by improving the institutional tasks of KPA either in quality, as well as institutional manegement KPA. (3) Aspects of culture either by increasing the involvement of the population of Key Non Governmental Organizations (NGOs) care about HIV/AIDS and high risk groups in planning the program and run the program as well as an evaluation of the program as a Field Officer (FO), Counselor, Case Manager. The establishment of culture/culture done by influencing the attitudes and behavior of continuously/routine so that you can understand, addressing the process of countermeasure and empathy, so as to minimize the discrimination against People Living with HIV/AIDS (ODHA).
\end{abstract}

Keywords: Implementation - Policy - HIV/AIDS - Surakarta 


\begin{abstract}
Abstrak
Artikel ini bertujuan untuk menganalisis Implementasi Kebijakan Pencegahan Dan Penanggulangan Human Immunodefisiency Virus Dan Aquired Immune Deficiency Syndrome (HIV/AIDS) di Kota Surakarta. Jenis penelitian dalam penulisan ini adalah non - doktrinal/ empiris, dengan mendasarkan pada konsep hukum yang ke 5 . Bentuk penelitian yang digunakan adalah analisis diagnostik. Jenis data primair, dan sumber data meliputi bahan hukum primer dan sekunder. Analisis datanya menggunakan analisis kualitatif. Berdasarkan hasil penelitian dan pembahasan sehubungan dengan masalah yang dikaji, dapat disimpulkan sebagai berikut : (1) Faktor-faktor yang menjadi penyebab belum maksimalnya penanggulangan HIV dan AIDS antara lain disebabkan masalah HIV dan AIDS belum dianggap masalah prioritas baik oleh sektor kesehatan maupun sektor pembangunan yang terkait; (2) dukungan politik yang belum memadai terhadap program; (3) belum terkordinasinya Komisi Penanggulangan AIDS (KPA) dan SKPD Kota Surakarta baik berupa arahan pengembangan, perencanaan dan pelaksanaan kebijakan dan program meskipun berbagai Surat Keputusan mengenai upaya penanggulangan bahkan pembiayaan telah dikeluarkan; dan (4) masih belum maksimalnya penyebaran dan akses informasi layanan kesehatan dan ketersediaan adanya layanan VCT, ARV bagi penderita dan orang beresiko tinggi terinfeksi HIV dan AIDS . Langkah - langkah yang harus dilakukan agar penanggulangan HIV /AIDS di Kota Surakarta antara lain: (1) Aspek substansi hukum dengan lebih memperkuat landasan operasional terutama petunjuk teknis dan petunjuk pelaksanaan yang mengatur mulai dari perencanaan, pelaksanaan, evaluasi, monitoring, sanksi). (2) Aspek struktur/ kelembagaan dengan meningkatkan fungsi dan tugas KPA baik secara kualitas, manegement serta kelembagaan KPA. (3) Aspek budaya/kultur baik dengan meningkatkan keterlibatan Populasi Kunci Lembaga Swadaya Masyarakat (LSM) peduli HIV/AIDS dan kelompok resiko tinggi dalam perencanaan program dan menjalankan program serta evaluasi program sebagai petugas lapangan (PL), Konselor, Manager Kasus . Pembentukan budaya/kultur dilakukan dengan cara mempengaruhi sikap dan perilaku secara terus menerus/rutin agar dapat memahami, menyikapi proses penanggulangan dan empati, sehingga dapat memperkecil diskriminasi terhadap ODHA.
\end{abstract}

Kata Kunci: Implementasi; Kebijakan; HIV/AIDS; Surakarta

\section{A. Pendahuluan}

Undang-Undang Nomor 36 Tahun 2009 tentang Kesehatan yang menyatakan bahwa kesehatan merupakan hak asasi manusia dan salah satu unsur kesejahteraan yang harus diwujudkan sesuai dengan cita-cita bangsa Indonesia sebagaimana dimaksud dalam Pancasila dan Undang-Undang Dasar Negara Republik Indonesia Tahun 1945. Ketentuan dalam konstitusi tersebut dapat dimaknai bahwa Negara memiliki tanggung jawab atas keberlangsungan kesehatan dan hidup setiap warga negaranya dari segala ancaman khususnya yang berkaitan dengan gangguan kesehatan warga Negara terhadap penyakit ataupun virus (Dewa Putu Yudi Pardita,
2014; 19) Adapun ancaman terbesar saat ini yang dihadapi khususnya oleh Indonesia adalah HIV dan AIDS. AIDS merupakan singkatan dari Acquired Immune Deficiency Syndrome yaitu suatu kumpulan gejala yang ditimbulkan oleh virus kekebalan tubuh manusia. Virus tersebut dinamakan HIV (Human Immunodeficiency Virus).

HIV/AIDS merupakan isu kesehatan yang cukup sensitif untuk dibicarakan. Hal ini berkaitan dengan sifat yang unik dari penyakit ini. Selain kasusnya yang seperti fenomena gunung es, stigma dan diskriminasi juga banyak dialami oleh penderita dan keluarganya. Tingginya stigma masyarakat terhadap penderita HIV/AIDS menyebabkan 
banyak perlakuan diskriminatif baik dalam hal pekerjaan, perawatan, pengobatan, pendidikan maupun dalam hal lainnya. Acquired Immune Deficiency Syndrome (AIDS) merupakan kumpulan gejala penyakit yang disebabkan oleh Human Immunodeficiency Virus (HIV) (Edi Suharto, 2015; 190)

Human Immunodeficiency Virus (HIV), merupakan retrovirus yang menjangkiti sel-sel sistem kekebalan tubuh manusia (terutama CD4 positive T-sel dan makrofag komponen-komponen utama sistem kekebalan sel), dan menghancurkan atau mengganggu fungsinya. Infeksi virus ini mengakibatkan terjadinya penurunan sistem kekebalan yang terus-menerus, yang akan mengakibatkan defisiensi kekebalan tubuh. Sedangkan Acquired Immunodeficiency Syndrome (AIDS) menggambarkan berbagai gejala dan infeksi yang terkait dengan menurunnya sistem kekebalan tubuh. Infeksi HIV telah ditetapkan sebagai penyebab AIDS, tingkat HIV dalam tubuh dan timbulnya berbagai infeksi tertentu merupakan indikator bahwa infeksi HIV telah berkembang menjadi AIDS (Hoyle, 2016; 12)

Indonesia memiliki target Millenium Development Goals (MDGs) pada tahun 2015 adalah mengendalikan penyebaran HIV/AIDS. Jumlah kasus HIV kumulatif sampai dengan Juni 2014 di Indonesia sebesar 142.950 kasus, sementara jumlah kasus AIDS kumulatif sampai Juni 2014 sebanyak 55.623 kasus, dengan jumlah kematian 9.760 kasus. Faktor risiko penularan HIV/AIDS di Indonesia adalah heteroseksual $(86,4 \%)$, homoseksual $(4,8 \%)$, pengguna narkoba suntik (2,6\%), dan transmisi perinatal $(3,6$ $\%$ ). Presentase kumulatif kasus AIDS tertinggi pada kelompok umur 20-29 tahun (34,5\%), diikutikelompok umur 30-39 tahun (28,7 \%), 40-49 tahun (10,6\%). Jumlah kumulatif AIDS pada golongan umur kurang dari 1 tahun sebesar 238 kasus $(0,45 \%$ dari total kasus $)$ (Spritia, 2016; 97)
Kasus HIV/AIDS di Indonesia hingga akhir Maret 2008 telah mencapai 17,990 kasus (6,130 kasus HIV dan 11,868 kasus AIDS). Sekitar $82 \%$ penderitanya adalah pria. Menurut golongan umur, proporsi penderita AIDS terbesar terdapat pada kelompok usia 20-29 tahun (53.6\%), kelompok umur 30-39 tahun (27.8\%), dan kelompok umur 40-49 tahun (7.9\%). Walaupun epidemi HIV di Indonesia biasanya dihubungkan dengan penggunaan jarum suntik (Penasun) dan pekerja seks perempuan (WPS), ternyata situasi epidemi HIV dan AIDS telah berubah. Pada tahun tahun mendatang, jumlah terbesar infeksi HIV baru akan terjadi diantara laki-laki yang laki-laki yang berhubungan seks dengan laki laki (LSL), dikuti oleh perempuan pada populasi umum (perempuan resiko rendah), yang terdiri dari perempuan terinfeksi melalui berhubungan seks dengan pasangan yang terinfeksi serta wanita yang mereka sendiri mungkin telah terlibat dalam perilaku beresiko pada tahun sebelumnya dan mereka yang sebenarnya telah terinfeksi HIV dan baru dapat terdeteksi di kemudian hari. Jumlah infeksi yang cukup besar terjadi pada laki-laki yang merupakan pelanggan pekerja seks dan lakilaki populasi umum, yang terdiri dari laki-laki yang terinfeksi melalui hubungan seksual dengan isteri-isteri mereka ditambah dengan laki-laki yang berhubungan seks dengan WPS pada tahun sebelumnya (Kementrian Kesehatan RI, 2016; 20)

Upaya pencegahan dan penanggulangan HIV dan AIDS tidak dapat dipisahkan dari aspek hukum dan hak Asasi manusia (HAM). Permasalahan pokok yang menyangkut hukum berkaitan dengan maraknya kasus HIV/ AIDS adalah bagaimana menyeimbangkan antara perlindungan kepentingan masyarakat dan kepentingan individu pengidap HIV dan penderita AIDS (Indar, 2010; 12) Aspek hukum dan HAM merupakan dua komponen yang sangat penting dan ikut berpengaruh terhadap berhasil tidaknya program penanggulangan 
yang dilaksanakan. Telah diketahui bahwa salah satu sifat utama dari fenomena HIV \& AIDS terletak pada keunikan dalam penularan dan pencegahannya. Berbeda dengan beberapa penyakit menular lainnya yang penularannya dibantu serta dipengaruhi oleh alam sekitar, pada HIV \& AIDS justru penularan dan pencegahannya berhubungan dengan dan atau tergantung pada perilaku manusia. Perilaku manusia selalu bersentuhan dengan hukum dan HAM. Hukum adalah suatu alat dengan dua fungsi utama, yakni sebagai social control dan social engineering. Sebagai social control, hukum dipakai sebagai alat untuk mengontrol perilaku tertentu dalam masyarakat sehingga perilaku tersebut tidak merugikan diri sendiri dan anggota masyarakat lainnya. Sebagai social engineering, hukum dijadikan sebagai alat yang dapat merekayasa sebuah masyarakat sesuai keinginan dan cita-cita hukum (Asa, Simplexius, dkk, 2009)

Pemerintah Surakarta dalam upaya untuk mencegah dan menanggulangi kasus HIV/AIDS telah membuat regulasi melalui Peraturan Walikota Nomor 4 A Tahun 2008 Tentang Penanggulangan Human Imunodeficiency Virus dan Acquired Imunodeficiency Syndrome (HIV dan AIDS) yang kemudian diperbaharui dengan Peraturan Daerah Kota Surakarta Nomor 12 Tahun 2014 tentang Pencegahan dan Penanggulangan Human Imunodeficiency Virus dan Acquired Imune Deficiency Syndrome dengan Peraturan Pelaksana melalui Peraturan Walikota Nomor 7 B Tahun 2015 tentang Petunjuk Pelaksanaan Peraturan Daerah Kota Surakarta Nomor 12 Tahun 2014 tentang Pencegahan dan Penanggulangan Human Imunodeficiency Virus dan Acquired Imunodeficiency Syndrome . Pada praktiknya, kebijakan pelaksanaan dari ketentuan Peraturan tersebut belum cukup efektif dalam upaya mencegah dan menanggulangi kasus HIV dan AIDS di Kota Surakarta. Beberapa contoh permasalahan yang terjadi diantaranya berdasarkan data yang didapat hingga bulan November 2015, ada sekitar 1.738 kasus dan jumlah ini lebih tinggi dibanding estimasi nasional. Estimasi KPA Nasional untuk penderita HIV/AIDS pada 2015 hanya 1.356 kasus. Tapi kenyataannya sampai akhir November 2015 sudah mencapai 1.738 kasus (Tommy Prawito, 2016 ) .

Berdasarkan uraian diatas dalam artikel ini hendak dibahas mengapa implementasi kebijakan pencegahan dan penanggulangan Human Immunodeficiency Virus dan Acquired Immune Deficiency Syndrome di Kota Surakarta belum dapat dilaksanakan dengan baik, dan bagaimana kebijakan yang harus dilakukan oleh Pemerintah Daerah Kota Surakarta dalam pencegahan dan penanggulangan HIV/AID di Kota Surakarta?

\section{B. Metode Penelitian}

Penelitian ini merupakan penelitian problem solution, karena penelitian ini berusaha untuk menemukan solusi yang berhubungan dengan permasalahan yang diteliti, sehingga jenis penelitiannya sosiologis. Penelitian ini memakai metode pendekatan non-doktrinal/ empiris. Penelitian ini menggunakan jenis pendekatan kualitatif. Berdasarkan konsep hukum maka peneliti menggunakan konsep hukum yang ke-5 (lima) yaitu Hukum dimaknai sebagai manifestasi makna-makna simbolik para pelaku sosial sebagai tampak dalam interaksi antar mereka. Hukum disini bukan dikonsepsikan sebagai rules tetapi sebagai regulatities yang terjadi dalam kehidupan sehari-hari atau dalam alam pengalaman, atau dalam istilah lain bersifat empiris. Penelitian ini menggunakan pendekatan non doctrinal. Data Primer dalam penelitian ini diperoleh melalui wawancara yang tidak terstruktur dengan beberapa nara sumber yaitu dengan memberikan pertanyaan yang menunjukkan keprihatinan, penjagaan, kerjasama yang pada akhirnya informan berpartisipasi untuk memberikan informasi. Teknik pengumpulan 
data, peneliti menggunakan teknik antara lain studi kepustakaan (library research), dan wawancara. Sesuai dengan metode pendekatan yang digunakan, maka dalam penelitian ini analisis data dengan menggunakan model analisis mengalir (flow model of analysis) maupun analisis interaktif (interactive model of analysis). Model analisis mengalir berarti melakukan analisis dengan menjalin secara paralel ketiga komponen analisis itu secara terpadu, baik sebelum mengumpulkan data, pada waktu mengumpulkan data, maupun sesudah mengumpulkan data. Aktivitas ketiga komponen analisis itu berbentuk interaksi dengan proses pengumpulan data sebagai proses siklus.

\section{Hasil Penelitian dan Pembahasan}

1. Faktor-Faktor Yang Mempengaruhi Kebijakan Pencegahan Dan Penanggulangan HIV/ AIDS di Kota Surakarta .

Pelaksanaan program dan kegiatan dalam penanggulangan HIV/AIDS di Kota Surakarta terdapat beberapa tantangan dan kendala secara umum yaitu (1) masalah HIV dan AIDS belum dianggap masalah prioritas baik oleh sektor kesehatan maupun sektor pembangunan yang terkait ; (2) dukungan politik yang belum memadai terhadap program promosi kondom dan pengurangan dampak buruk NAPZA suntik padahal kedua program ini merupakan program pokok upaya penanggulangan HIV/ AIDS; (3) belum spesifiknya/belum jelas bagaimana strategi pelaksanaan program dalam konteks menghadapi tantangan program; (4) Belum terkordinasinya Komisi Penanggulangan AIDS Daerah (KPAD) Kota Surakarta baik berupa arahan pengembangan, perencanaan dan pelaksanaan kebijakan dan program meskipun berbagai Surat Keputusan mengenai upaya penanggulangan bahkan pembiayaan telah dikeluarkan; (5) belum terwakilinya anggota LSM Peduli AIDS dan kurang dilibatkan dalam sosialisasi kebijakan dan pelaksanaan program; (6) tantangan terberat dalam upaya penanggulangan HIV dan AIDS adalah stigmatisasi terhadap orang orang yang terinfeksi/ODHA; (7) belum terpadunya program-program antara SKPD baik dalam perencanaan dan pembiayaan dalam upaya penanggulangan HIV dan AIDS; (8) Populasi kunci dalam Per Educator yang dilatih tidak mempunyai tingkat pendidikan yang baik; (9) program pemakaian kondom dalam seks beresiko tinggi belum dapat dilakukan secara baik, sehingga temuan orang yang terinfeksi HIV dan AIDS tetap diketemukan; (10) masih belum maksimalnya penyebaran dan akses informasi layanan kesehatan dan ketersediaan adanya layanan VCT, ARV bagi penderita dan orang beresiko tinggi terinfeksi HIV dan AIDS

Faktor Substansi/Perundangundangan: Meskipun secara normatif Pemerintah Daerah (Pemda) sudah menunjukkan komitmen awalnya dengan menghasilkan kebijakan pencegahan dan penanggulangan HIV dan AIDS di daerah melalui Peraturan Daerah (Perda), pada kenyataannya HIV dan AIDS tetap belum menjadi prioritas daerah. Ini bias jika dilihat dari keengganan pemda untuk mengalokasikan penganggaran yang memadai bagi penanggulangan HIV dan AIDS. Pendanaan penanggulangan HIV dan AIDS yang bersumber dari Anggaran Pendapatan dan Belanja Daerah (APBD) melalui Satuan Kerja Pemerintah Daerah (SKPD) terkait masih terbatas. Upaya penanggulangan HIV \& AIDS ke dalam sistem kesehatan nasional memperlihatkan banyaknya produk kebijakan tidak berkorelasi langsung dengan efektivitas upaya penanggulangan 
AIDS. Perangkat hukum lebih merupakan upaya pemenuhan aspek legalitas dan prosedural sebagai bukti adanya itikad dari pemerintah dalam merespons epidemi AIDS, tetapi komitmen secara praktis dalam pendanaan masih sangat kecil. Ini tidak terlepas dari banyaknya intervensi global yang membawa bantuan dalam jumlah yang besar, sehingga pemerintah memandang dukungan asing sudah mencukupi. Ketika dukungan asing tidak lagi ada, pemerintah tidak siap. Kebijakan penanggulangan HIV \& AIDS menunjukkan, konteks tualisasi kebijakan dan peraturan di tingkat nasional terkait penanggulangan HIV \& AIDS masih jauh dari harapan. Dalam SRAD, misalnya, upaya penanggulangan AIDS masih belum menjadi prioritas. Padahal kontekstualisasi SRAD yang berbasis pada data epidemi lokal dan penganggaran dari sumber pembiayaan lokal (APBD) maupun kerja sama sektor swasta lain berkontribusi pada kemandirian dalam pencegahan HIV \& AIDS yang strategis, mengurangi ketergantungan pada donor asing dalam aspek pembiayaan, serta efektivitas program sesuai dengan status epidemi HIV dan konteks persoalan di daerah masing-masing, baik provinsi maupun kabupaten/kota. Belum spesifiknya/ belum jelas strategi pelaksanaan program dalam konteks menghadapi tantangan program penanggulangan HIV dan AIDS . Penanggulangan HIV dan AIDS selama ini hanya dilihat sebagai persoalan medis semata yang menjadi tanggung jawab Dinkes dan unit-unit pelayanan kesehatan, sehingga keterlibatan dari SKPD atau instansi pemda non-kesehatan menjadi minimal .

Indikasi ini terlihat dari dua hal, pertama ialah tidak adanya atau minimnya alokasi APBD untuk penanggulangan HIV dan AIDS bagi SKPD non-kesehatan, dan kedua ialah ketakaktifan SKPD dalam KPAD walaupun secara struktur merupakan bagian dari KPAD, oleh karena itu dengan konteks politik daerah seperti ini, HIV dan AIDS sulit menjadi isu yang diprioritaskan oleh daerah. Selain masalah akses, hambatan terkait hukum lainnya muncul karena tidak adanya sanksi terhadap pengabaian kewajiban yang dilakukan oleh SKPD sebagai penanggung jawab upaya penanggulangan HIV dan AIDS. Perda tentang Penanggulangan HIV dan AIDS hanya mengatur pemberian sanksi kepada petugas kesehatan, penyedia fasilitas kesehatan, dan pengelola atau pemilik tempat hiburan. Tidak ada insentif dan disinsentif bagi SKPD untuk melakukan kewajibannya dalam penanggulangan HIV dan AIDS. Sudah ada pendanaan dari sektor swasta melalui Corporate Social Responsibility (CSR) pun, pengelolaannya masih dilakukan oleh sektor swasta secara sendiri-sendiri dan hanya difokuskan pada kegiatan-kegiatan yang berorientasi pada pencegahan dalam bentuk sosialisasi dan pengelolaan pendanaan terbatas pada kegiatan yang sifatnya insidental dan belum dijadikan bagian dari upaya penanggulangan HIV dan AIDS yang strategis dan berkelanjutan.

Faktor Struktur/Kelembagaan: Implementasi kebijakan ini dipengaruhi juga oleh faktor kapasitas (sumber daya) yang masih terbatas. Keberadaan peraturan dan kebijakan tidak dibarengi dengan ketersediaan sumber daya yang kompeten, sehingga peraturan dan kebijakan itu tidak memberikan nilai lebih dalam upaya merespons epidemi di tingkat lokal. Keterbatasan ini berdampak langsung pada proses perencanaan, implementasi, dan evaluasi intervensi program, di antaranya alokasi pendanaan yang terbatas dan ketidakpahaman mekanisme perencanaan. 
Sumber daya manusia (SDM) memainkan peran signifikan dalam sistem kesehatan dan penanggulangan HIV \& AIDS. Maka, diperlukan integrasi SDM AIDS dalam sistem kesehatan untuk memperbaiki kesenjangan ketersediaan tenaga AIDS. Penyediaan SDM kesehatan ini kini mendapatkan tantangan dari desentralisasi yang memberikan kewenangan daerah untuk menyediakan tenaga kesehatan. Respons terhadap tren epidemi di suatu wilayah tidak dapat dilepaskan dari konteks kebijakan setempat. Dalam konteks desentralisasi, Peraturan Pemerintah (PP) Nomor 38 Tahun 2007 tentang Pembagian Urusan Pemerintahan antara Pemerintah, Pemerintah Daerah Provinsi, dan Pemerintah Daerah Kabupaten/ Kota telah mengamanatkan pembagian kewenangan antara pemerintah kabupaten/ kota terkait pengelolaan, penempatan, pendayagunaan, peningkatan kapasitas, registrasi, pembinaan, dan pengawasan SDM kesehatan. Salah satu cara untuk melihat integrasi SDM AIDS dalam sistem kesehatan ialah dengan mengkaji apakah pengadaan sampai pembinaan dan pengawasan SDM AIDS sudah mengikuti sistem SDM kesehatan pada umumnya. Namun demikian ada kecenderungan kesamaan pola dalam respons pencegahan HIV dan AIDS, khususnya terkait dengan model intervensi dan target standar penjangkauan dan pendampingan.

Faktor Kultural/Budaya: Faktor pelaku (aktor) menjadi salah satu penentu dalam implementasi kebijakan AIDS. AIDS merupakan masalah yang tidak hanya menyangkut epidemi, tetapi juga terkait dengan faktor sosial, ekonomi, politik, dan budaya. Keaktifan para aktor dalam implementasi kebijakan menjadi penentu utama, bahkan ditemukan bukti bahwa meski suatu daerah belum memiliki kebijakan penanggulangan
AIDS, tapi karena terdapat pelaku-pelaku yang aktif dan punya perhatian terhadap masalah AIDS, intervensi program dapat berjalan efisien. Dalam konteks budaya Indonesia, faktor ketokohan menjadi aspek penentu keberhasilan program . Jenis-jenis respons pencegahan yang ada di daerah antara lain tes dan konseling HIV, PPIA, PMTS dengan pendistribusian kondom, program LASS, dan terapi metadon untuk kelompok penasun, serta berbagai program komunikasi, informasi dan edukasi (KIE) yang menyasar kepada popolasi umum khususnya remaja, ibuibu rumah tangga, dan laki-laki berisiko rendah masih terlihat kurang diminati masyarakat. Aspek psikososial dari ODHA belum memperoleh perhatian karena keterbatasan kapasitas fasilitas pelayanan kesehatan untuk menyediakan layanan sesuai standar. Padahal ketersediaan dukungan psikososial dalam perawatan ARV merupakan unsur penting kaitannya dengan tingkat drop out dan kepatuhan berobat. Meskipun sudah menjalankan pendekatan Layanan Komprehensif Berkesinambungan (LKB) dengan mengembangkan integrasi layanan mulai dari koordinasi pemangku kepentingan kunci HIV dan AIDS lintas-sektor dengan melibatkan peran aktif masyarakat. Ini merupakan upaya mengintegrasikan layanan HIV dan AIDS yang didelegasikan sampai ke tingkat layanan primer mulai dari diagnosis, tes HIV (Voluntary Counselling Test/VCT dan Providerinitiated Counselling and Testing/PICT), link to care, dan pendampingan kepatuhan bagi ODHA yang terapi ARV. Mitigasi dampak merupakan respons paling minimal dalam penanggulangan HIV dan AIDS karena respons mitigasi terindikasi belum berjalan dan tidak terkoordinasi. Ini mengindikasikan bahwa pemahaman SKPD anggota KPAD terkait continuum 
of care PDP ODHA masih terbatasselain ketakjelasan peran SKPD sebagai anggota KPAD yang memiliki peran dan tanggung jawab untuk ambil bagian dalam penanggulangan HIV dan AIDS. Di samping itu, dukungan terhadap ODHA lebih banyak dilakukan oleh LSM dan tokoh masyarakat yang dalam praktiknya juga banyak tidak berkoordinasi dengan dinas terkait.

\section{Langkah-langkah yang harus dilakukan dalam upaya penanggulangan HIV dan AIDS di Kota Surakarta.}

Secara teoretis, pendekatan horizontal dalam bidang kesehatan (seperti penanggulangan HIV \& AIDS) dengan pengandaian adanya integrasi lintas sektor dan lintas program dalam merespons problem epidemi bisa menjadi visi pembangunan kesehatan ke depan yang komprehensif dan berkesinambungan, sehingga layanan yang diberikan lebih efektif dan efisien harus dilakukan antara lain; Pertama, di samping kebijakan yang progresif dan ketersediaan sumber daya (manusia, biaya, teknologi, dan pengetahuan) yang pada galibnya masih bersifat vertikal, faktor penentu keberhasilan intervensi kesehatan dalam penanggulangan HIV \& AIDS adalah rasa kepemilikan dan komitmen dari berbagai pihak terhadap program. LKB dirancang untuk semakin mendekatkan layanan hingga ke tingkat komunitas dengan membangun keterlibatan stakeholders lintas sektor. Tantangan yang cukup besar: ketersediaan sumber daya kesehatan yang memenuhi kualitas, sumber pembiayaan yang jelas, dan komitmen dari para pemangku kepentingan. Rasa kepemilikan terhadap LKB dapat dilihat dari sejauh mana setiap pihak berkoordinasi dan memberikan kontribusi secara nyata untuk mewujudkan layanan yang berkesinambungan dan komprehensif, misalnya dalam hal cost sharing proses intervensi yang diberikan oleh Dinas Kesehatan dan Komisi Penanggulangan AIDS (KPA). Kedua, masalah jaminan kualitas layanan dari tenaga kesehatan dan tenaga non kesehatan menjadi krusial dalam rangka memberikan layanan yang efektif dan berkualitas. Komitmen para pemangku kepentingan untuk memberikan layanan yang responsif dan sensitif terhadap kebutuhan pasien merupakan prasyarat yang penting. Kualitas ini berbanding lurus dengan kapasitas dari semua pemangku kepentingan. Kapasitas dan pengetahuan yang baik akan berdampak langsung pada peningkatan kualitas layanan. Ketiga, indikasi efektivitas dari integrasi program LKB dalam sistem kesehatan umum adalah meningkatnya kepuasan pasien dalam beberapa aspek layanan, seperti tingkat kecepatan layanan, kapabilitas tenaga kesehatan dalam memberikan layanan, perlakuan yang lebih ramah dari tenaga kesehatan, dan terjaganya kerahasiaan pasien.

Meningkatkan nilai tambah dari keberadaan kebijakan AIDS, terdapat beberapa faktor kunci yang perlu diperhatikan dalam proses implementasi kebijakan. Salah satunya, penting untuk menggali faktor-faktor yang menjadi pendukung dan penghalang (barrier) implementasi kebijakan.

Secara nyata langkah-langkah yang harus dilakukan dalam upaya penanggulangan HIV dan AIDS di Kota Surakarta adalah melalui program program terpadu baik Satuan Kerja Perangkat Daerah (KPAD, Stake Holder (WPS, LSL, PPS, Waria, IDU'S) dan Masyarakat (WPA, LSM, Perusahaan dsb). Dari aspek substansi hukum antara lain dengan lebih memperkuat landasan 
operasional terutama petunjuk teknis dan petunjuk pelaksanaan yang mengatur mulai dari perencanaan, pelaksanaan, evaluasi, monitoring, sanksi) . Dari aspek struktur/ kelembagaan antara lain meningkatkan fungsi dan tugas KPA baik secara kualitas, manegement serta kelembagaan KPA dan program pendukung berupa pendanaan/ pengalokasian anggaran pada setiap SKPD terkait. Meningkatkan akses dan kualitas pelayanan kesehatan bagi ODHA dan anak dengan HIV dan AIDS/ADHA, dan kelompok yang beresiko tinggi tertular (RISTI), dan Orang Yang Hidup dengan HIV dan AIDS/OHIDHA) . Meningkatkan keterlibatan swasta dan pelaku usaha/ industri/perusahaan khususnya terhadap karyawan dan penggalangan dana, sarana dan prasarana yang mendukung program penanggulangan HIV dan AIDS di lingkungannya. Pemenuhan kebutuhan Sumber Daya Manusia dilakukan melalui pengadaan tenaga kerja multiplier, pengalihan tugas, dan penambahan jumlah staf melalui jalur reguler atau pengadaan khusus lewat tenaga honorer maupun jalur proyek. Tenaga outreach, konselor, dan manajer kasus, misalnya, dapat direkrut sebagai tenaga kesehatan melalui skema PNS atau tenaga honorer. Memberikan kesempatan sektor non pemerintah atau masyarakat sipil yang terlatih, pemerintah turut andil mewujudkan pengakuan terhadap kesetaraan serta mengurangi stigma dan diskriminasi. Skema lain ialah mekanisme pengalihan tugas, yang meliputi perluasan tanggung jawab atas pasien HIV dari spesialis/ internis ke dokter umum, pergeseran tanggung jawab beberapa layanan dari dokter kepada perawat, dan rangkap tugas perawat sebagai teknisi laboratorium sederhana (untuk menyelesaikan masalah kekurangan kapasitas laboratorium yang menghambat ekspansi pengobatan).
Artinya, pengelolaan SDM AIDS dapat lebih direncanakan dengan melihat kebutuhan dan kapasitas tenaga kesehatan di suatu daerah, sehingga mutasi tenaga kesehatan terlatih tidak menghambat keberlanjutan layanan HIV \& AIDS

Dari aspek budaya/kultur baik petugas maupun stake holder dan masyarakat antara lain meningkatkan pemahaman masyarakat tentang Hiv dan Aids dengan benar dan peran serta masyarakat dalam upaya penanggulangan Hiv dan Aids - Meningkatkan keterlibatan Populasi Kunci dengan cara mengundang Lembaga Swadaya Masyarakat (LSM) peduli Hiv dan Aids dan kelompok resiko tinggi dalam perencanaan program dan menjalankan program serta evaluasi program sebagai petugas lapangan (PL), Konselor, Manager Kasus dalam Komisi Penanggulangan Aids . Dalam pembentukan budaya/kultur dilakukan dengan cara mempengaruhi sikap dan perilaku secara terus menerus/rutin agar dapat memahami, menyikapi proses penanggulangan dan empati, sehingga diharapkan memperkecil diskriminasi terhadap ODHA.

Adapun langkah - langkah kongkrit yang harus dilakukan dalam upaya penanggulangan HIV dan AIDS antara lain berupa (1) sosialisasi dengan melalui komunikasi informasi dan edukasi (KIE) baik melalui sarana langsung (penyuluhan, seminar/pelatihan, screning darah PMI) maupun tidak langsung (melalui poster/iklan/siaran radio - TV . layanan hot line); (2) meningkatkan kordinasi melalui pertemuan dengan stake holder secara rutin dan pemberdayaan ODHA dan WPA melalui kegiatan kegiatan pelatihan, advokasi; (3) program pencegahan penularan HIV dan AIDS di lingkungan tempat kerja dengan memberikan pengetahuan, pemahaman 
serta perlindungan bagi karyawan/pekerja . Hal ini dimungkinkan adanya program komperhensif dari Perusahaan dalam upaya mendukung program pemerintah kota Surakarta dalam penanggulangan HIV/AIDS; (4) membuka akses pelayanan kesehatan(promosi, pengobatan, rehabilitasi) khususnya $\mathrm{VCT} / \mathrm{KTS}$, IMS, CST/PDP di tiap Puskesmas dan menjamin tersedianya Layanan Komperhensif Berkesinambungan/LKB; (5) pemberdayaan dan layanan sosial bagi ODHA dengan memberikan bekal pengetahuan dan pelatihan ketrampilan dalam bidang sosial dan ekonomi; (6) melakukan monitoring dan evaluasi terhadap KPA yang memberikan LKB sebagai dasar pembuatan kebijakan pelaksanaan secara berkala; dan (7) mengevaluasi dan pengembangan kebijakan penanggulangan HIV dan AIDS melalui regulasi dalam peraturan daerah, peraturan walikota, keputusan walikota, terutama yang menyangkut petunjuk teknis/pelaksanaan program program, baik regulasi, penataan SDM, penganggaran/alokasi pembiayaan melalui APBD maupun partisipasi warga dan institusi swasta.

\section{Simpulan}

Dari hasil penelitian dan pembahasan yang telah dilakukan, maka penulis dapat memberikan kesimpulan sesuai dengan permasalahan yang diteliti sebagai berikut :

1. Faktor-faktor yang menjadi penyebab belum maksimalnya penanggulangan HIV dan AIDS antara lain disebabkan masalah ini belum dianggap masalah prioritas baik oleh sektor kesehatan maupun sektor pembangunan yang terkait; dukungan politik yang belum memadai terhadap program dan belum spesifiknya/belum jelas bagaimana strategi pelaksanaan program dalam konteks menghadapi tantangan program; belum terkordinasinya Komisi Penanggulangan AIDS (KPA) dan SKPD Kota Surakarta baik berupa arahan pengembangan, perencanaan dan pelaksanaan kebijakan dan program meskipun berbagai Surat Keputusan mengenai upaya penanggulangan bahkan pembiayaan telah dikeluarkan; belum/ kurang dilibatkan dalam sosialisasi kebijakan dan pelaksanaan program;masih tinggi stigmatisasi/diskriminasi terhadap orang orang yang terinfeksi/ODHA; dan masih belum maksimalnya penyebaran dan akses informasi layanan kesehatan dan ketersediaan adanya layanan VCT, ARV bagi penderita dan orang beresiko tinggi terinfeksi HIV dan AIDS .

2. Langkah - langkah yang harus dilakukan agar penanggulangan HIV dan AIDS di Kota Surakarta dapat berjalan dengan baik antara lain : Aspek substansi hukum antara lain dengan lebih memperkuat landasan operasional terutama petunjuk teknis dan petunjuk pelaksanaan yang mengatur mulai dari perencanaan, pelaksanaan, evaluasi, monitoring, dan sanksi . Aspek struktur/kelembagaan antara lain meningkatkan fungsi dan tugas KPA baik secara kualitas, manegement serta kelembagaan KPA dan program pendukung berupa pendanaan/ pengalokasian anggaran pada setiap SKPD terkait . Meningkatkan akses dan kualitas pelayanan kesehatan bagi ODHA dan anak dengan HIV dan AIDS (ADHA), dan kelompok yang beresiko tinggi (RISTI) dan Orang Yang Hidup dengan HIV danAIDS (OHIDHA). Meningkatkan keterlibatan swasta dan pelaku usaha/ industri/perusahaan khususnya terhadap karyawan dan penggalangan dana, sarana dan prasarana yang mendukung program penanggulangan HIV dan AIDS di lingkungannya. Aspek budaya/kultur baik petugas maupun stake holder dan 
masyarakat antara lain meningkatkan pemahaman masyarakat tentang HIV dan AIDS dengan benar dalam upaya penanggulangan HIV dan AIDS . Dalam pembentukan budaya/kultur dilakukan dengan cara mempengaruhi sikap dan perilaku secara terus menerus/rutin agar dapat memahami, menyikapi proses penanggulangan dan empati, sehingga diharapkan memperkecil diskriminasi terhadap ODHA.

\section{E. Saran}

1. Diperlukan intervensi yang dilakukan melalui pelatihan tenaga kesehatan dan tenaga nonkesehatan untuk fasilitas pelayanan kesehatan (fasyankes) primer dan sekunder yang di-setting LKB. Peningkatan pengetahuan dan skills yang berdampak pada kepercayaan diri tenaga kesehatan dan tenaga non kesehatan dalam memberikan layanan kepada pasien ODHA. Peningkatan kapasitas ini berdampak langsung pada kemampuan tenaga kesehatan dan tenaga non kesehatan dalam mewujudkan efisiensi waktu, efektivitas biaya, aksesibilitas, dan pelibatan komunitas.

2. Pengembangan Strategi Rencana Aksi Daerah (SRAD) penanggulangan HIV \& AIDS. Idealnya, pengembangan SRAD HIV \& AIDS sejalan dengan mekanisme perencanaan pembangunan daerah. Proses pengembangan SRAD dilakukan melalui kajian yang melibatkan berbagai pihak, terutama pemangku kepentingan program penanggulangan HIV \& AIDS, seperti kelompok ODHA, populasi kunci, sektor komunitas, pemerintah, dan pihak swasta. Pengembangan SRAD juga penting untuk merujuk pada pendekatan perencanaan berbasis bukti dan data (evidence-based planning), dimulai dari kajian mengenai gambaran situasi epidemi HIV \& AIDS serta respons program dan capaian yang telah dihasilkan sampai saat ini.

3. Permasalahan HIV dan AIDS merupakan isu kompleks yang penanganannya membutuhkan keterlibatan berbagai pihak yang bersifat multisektoral. Untuk menggerakkan respons multisektor tersebut, diperlukan komitmen politik yang tinggi dari para pemangku kepentingan dengan menjadikan penanggulangan HIV dan AIDS menjadi prioritas daerah, khususnya mengenai alokasi pengganggaran/pendanaan melalui satuan Kerja Pemerintah Daerah (SKPD) maupun sumber lainnya.

\section{F. Daftar Pustaka}

\section{Buku:}

Dewa Putu Yudi Pardita 2014 Analisis Dampak Sosial, Ekonomi, Dan Psikologis Penderita HIV Aids Di Kota Denpasar. Denpasar: Program Pascasarjana Universitas Udayana.

Depdiknas. 2003. Kamus Besar Bahasa Indonesia. Edisi Ketiga. Jakarta : Penerbit Balai Pustaka.

Prasetya Irawan. 2006. Penelitian Kualitatif dan Kuantitatif untuk Ilmu-ilmu Sosial. Depok: FISIP UI.

Kementrian Kesehatan Republik Indonesia. 2011. Pedoman Nasional Tatalaksana Klinis Infeksi HIV dan Terapi Antiretroviral Pada Orang Dewasa. Jakarta: Kementrian Kesehatan Republik Indonesia.

Paulus Hadi Suprapto. tanpa tahun. Metodelogi Penelitian Hukum. Bahan Kuliah Magister Ilmu Hukum UNDIP. Semarang. 
Ronald Hutapea. 2014. AIDS dan PMS Dan Pemerkosaan. Jakarta : Rineka Cipta.

Ronny Hanitjo Soemitro. 1994. Metodelogi Penelitian Hukum. Jakarta : Ghalia Indonesia.

Satjipto Rahardjo. 1993. Masalah Penegakan Hukum: Suatu Tinjauan Sosiologis, Jakarta: Badan Pembinaan Hukum Nasional.

Soedarto. 1986. Kapita Selekta Hukum Pidana. Bandung : Alumni.

\section{Jurnal/Makalah, Tesis:}

Argyo Demartoto. 2006. ODHA. "Masalah Sosial dan Pemecahannya".JPP (Jurnal Penduduk dan Pembangunan). Vol. 6 No. 2. Surakarta: Jurusan Sosiologi FISIP Universitas Sebelas Maret.

Edi Suharto. 2016. “Analisis Kebijakan PublikP, dalam Abdul Najib, Pola Kebijakan Penanggulangan dan Penularan Terhadap Perkembangan Virus HIV/AIDS dan Peran Bagi Pekerja Sosial. Artikel: Jurnal Panggung Hukum, edisi Vol. 1. No. 2. Juni.

Henni Kusuma. 2011. "Hubungan Antara Depresi dan Dukungan Keluarga
Dengan Kualitas Hidup Pasien HIV/ AIDS Yang Menjalani Perawatan di RSUPN Cipto Mangunkusumo". Tesis. Depok : Program Pascasarjana Fakultas Ilmu Keperawatan Medikal Bedah Universitas Indonesia.

Spritia. 2016. "Statistik Kasus Aids Di Indonesia”. Jurnal Kesehatan Masyarakat. Edisi Kemas 11 (2) (2016) $\mathrm{XX}-\mathrm{XX}$.

\section{Internet:}

http://etd.repository.ugm.ac.id/ downloadfile/71839/.../S2-2014323765-chapter1.pdf.

http://lib.ui.ac.id/file?file=digital/125929-S5471-Deskripsi\%20dan-Literatur.pdf.

http://eprints.uns.ac.id/21424/2/d0111054 bab1.pdf.

http://jateng.tribunnews.com/2015/11/29/ penderita-hivaids-di-solo-raya-capairibuan-orang.

http://www.tempointeraktif.com/hg/ nusa/2009/05/06.

http://www.gunadarma.ac.id/library/ articles/graduate/psychology/2009/ Artikel_10503068.pdf. 